\title{
THE EFFECT OF HIGH SUMMER TEMPERATURES ON REPRODUCTION IN HOLSTEIN AND CZECH FLECKVIEH
}

\author{
Jiří Bezdíček ${ }^{1}$, Andrea Nesvadbová1 ${ }^{1}$ František Louda² \\ ${ }^{1}$ Palacký University Olomouc, Department of Zoology and Laboratory of Ornithology, Faculty of Science, \\ 17. listopadu 50, 77146 Olomouc, Czech Republic \\ ${ }^{2}$ Research Institute for Cattle Breeding Rapotin, Ltd., Department of Feed, Nutrition, Breeding and Reproduction, \\ Výzkumníků 267, 78813 Vikýřovice, Czech Republic
}

Link to this article: https://doi.org/10.11118/actaun202068010009

Received: 29. 11. 2019, Accepted: 7. 2. 2020

To cite this article: BEZDÍČEK JIŘÍ, NESVADBOVÁ ANDREA, LOUDA FRANTIŠEK. 2020. The Effect of High Summer Temperatures on Reproduction in Holstein and Czech Fleckvieh. Acta Universitatis Agriculturae et Silviculturae Mendelianae Brunensis, 68(1): 9-16.

\begin{abstract}
The aim of this study was to evaluate the effect of the hot summer season on the length of service period (number of days from calving to the next conception). For the analysis was created two databases of twins. Twins had the same sire and dam and the first and second lactations took place on the same farm. In the first database (105 pairs) one of the twins was calved (and had the following service period) during the summer months and the second of the twin was calved in the cooler months. To compare the difference in service period between twins in the hot and cool seasons, it was made also second group of twin pairs with reproduction only during the cool period of the year (cool vs. cool season; 58 pairs). The data were analysed using PROC GLM of Statistica ${ }^{\circledR}$. In addition to season, the effect of breed (Holstein, Czech Fleckvieh), milk production at $1^{\text {st }}$ lactation and calving year were also taken into consideration. The results showed a significantly longer service period in the summer (133.8 days) than in the cool months (114.7 days). In the case of twins with reproduction in the cool months of the year, the difference between length of service period was shorter and insignificant (113.6 vs. 119.4 days).
\end{abstract}

Keywords: heat stress, service period

\section{INTRODUCTION}

Short term stress is vital to the survival of animals in the wild. Longer term or prolonged stress however, is associated with reduction of production and reproduction yields. In livestock, efforts are generally made to minimize stress but one important phenomenon in cattle breeding is heat stress during the summer hot period and that may affect reproduction and production (Al-Katanani et al., 1999; Morton et al., 2007; Schüller et al., 2014; De Rensis et al., 2002). In relation to reproduction heat stress can be monitored at different levels. The rate of conception has been proven to be influenced by heat stress (Schüller et al., 2014; Chebel et al., 2004; Morton et al., 2007 and others). The effect of heat stress on nonreturn rate was studied by Al-Katanani et al. (1999) and Ravagnolo et al. (2002). From the viewpoint of services per conception heat stress was evaluated by Ray et al. (1992). Research on heat stress has also focused on gametogenesis and subsequent development of embryos (Al-Katanani et al., 2002; Ryan et al., 1993; Bezdíček et al., 2015).

In farm livestock practice, an important reproduction trait is the number of days between calving and the beginning of conception (service period), which was studied in relation to heat stress by Oseni et al. (2004). In this study the authors report 
that in Holstein cows, spring calving is associated with the longest service period, while the shortest was in the fall and winter season. Similar results were reported by Ray et al. (1992), who also found a reduction in reproduction measured as longer service period, longer calving interval and higher count of services per conception during the hot months.

Research on heat stress in relation to oocyte and embryo development was studied in vitro by Al-Katanani et al. (2002). These authors found that the proportion of embryos developed to blastocysts (on day 8 after insemination) was lower during the warm season than the cold season. They concluded that although the cleavage rate of oocytes was unaffected in the hot season, there was a reduction in development to the blastocyst stage.

Similar findings in this area are reported by Rocha et al. (1998). Authors found a higher production of normal oocytes (75.9\%) during the cold season (41.0\%) and the percentage of oocytes developing to the 8-cell and morula stage in the cool season was (65.4 and 46.6\%, respectively). In contrast, in the hot season it was only 21.2 and 6.0\% (Rocha et al., 1998).

Similar findings were reported by Bezdíček et al. (2015) in terms of embryo transfer results in Holstein cattle. The authors reported a significantly lower number of embryos in the hot months than in the cold period of the year and a lower proportion of transferable embryos. In a later study, the same authors found an influence of heat stress on the number of ovarian follicles and on the lower number of aspirated oocytes in the summer months (Bezdíček et al., 2016).

Ferreira et al. (2011) also reported better reproduction results in Holstein cattle in the cold months. There were a higher number of live oocytes in the cold than in the hot season (12.51 vs. 8.43). Similarly, Putney et al. (1988) found, that stressed superovulated Holstein heifers had a higher count of retarded and abnormal embryos. Similar findings were reported by Ryan et al. (1993). Authors present reduced survival of embryos in the hot summer period compared to cooler periods of the year (embryo survival 59 vs. 27\%). These conclusions show that the influence of heat stress can be observed up to gamete development. The negative influence of heat stress was demonstrated not only on females gametes (oocyte development) but also on the bulls sperm quality (Mathevon et al., 1998; Nichi et al., 2006).

In studying heat stress in livestock, it is also very important to take into the consideration breed as many studies have shown significant differences between breeds. Some breeds are thermotolerant such as Brahman and Senepol and some are thermosensitive (eg Holstein, Angus). Differences were found, for example, in embryo resistance to heat stress and in thermotolerance to apoptosis response in lymphocytes too (Paula-Lopes et al., 2003). Similar findings are reported by Hernández-
Cerón et al., 2004 who showed that embryos from Brahman and Romosinuano breeds were more resistant to heat stress than Angus breed embryos (Hernández-Cerón et al., 2004). In general, the research shows that breed is a crucial factor in relation to heat stress.

Research on thermoregulation in animals also shows the impact of the individual's genetic make up. The effect of genetics can be monitored at different levels. Specific genes related to heta stress were reviewed in Collier et al. (2008). The authors also covered the intra- and extracellular signals and metabolic changes in heat stressed animals. A significant part focuses on the body surface temperature and hair coat characteristics, where activation of thermoregulation systems and heat stresses begins. Similarly, Dikmen et al. (2008) proved that slick-haired holstein cows can regulate body temperature in periods of heat stress more effectively than wild-type holstein cows.

The temperature load of the animals depended not only on the ambient temperature but also on other factors such as humidity. Therefore in many previous studies of heat stress (Mader et al., 2006) was used the Temperature Humidity Index (THI; Buffington et al., 1981), which includes the air temperature and relative humidity. From this point of view categorized Armstrong (1994) the level of THI (Temperature Humidity Index) into 5 classes: no stress $(\mathrm{THI}<72)$, mild stress $(\mathrm{THI}=72-78)$, moderate stress (THI $=79-88)$, severe stress $($ THI $=89-98)$ and danger stress $($ THI $>98)$. This index has been used in this study too.

Overall, the literature shows that heat stress effects on and reproduction are due to a number of factors (breed, season, genes) and it is an important included this effects into the analyzes. In our study we used full twins (cows with identical father and mother) to eliminate the effect of ancestor. These had the first lactation on the same farm as well. As differences between full siblings may be in the length of service period, we compared also service period between the full siblings in the thermoneutral period as well (cool vs. cool season).

\section{MATERIALS AND METHODS}

The objective of this study was to evaluate cattle reproduction in the hot summer months. The reproduction trait assessed was the service period (number of days between calving to the next conception) after the first lactation.

For the analysis was created two databases of twins. In the first database (105 pairs) one of the twins were calved during the summer months (calving June and July) and the second twin was calved in the cool months of the year (September to May). Animals calved in August were excluded from monitoring because the service period of these animals was at the boundary of hot and cool periods. It can be assumed, that between the full 
twins, there would be a difference in the length of service period. For this reason, we created a second database and compared the differences between the twins in the cool season too (COOL1 vs. COOL2 season). In this second database (58 pairs) one of the twins had calved in the cool season (September to December) and the second twins also in the cool season (January to April). Twins in both databases (not verified as genetically identical) had the same father and mother and the first and second lactations took place on the same farm. The twins consisted from embryo transfers or natural twin births. The use of twins eliminated the influence of ancestor (father and mother).

Data were analysed using PROC GLM of Statistica ${ }^{\circledR}$ using different effects and using t-test (dependent samples). A test for homogeneity was done using the Cochran-Hartley-Bartlett test and residuals. The results show the suitability of the GLM method (Fig. 1).

Selected effects were included in the final calculation: the season effect (hot vs. cool; cool vs. cool season), effect of breed (Holstein, Czech Fleckvieh), milk production at $1^{\text {st }}$ lactation and calving year.

The effects of heat season (and other factors) were estimated from the model as follows:

$Y_{i j k l}=\mu+$ Season $_{i}+$ Year $_{j}+$ Milk $_{k}+$ Breed $_{l}+e_{i j k l}$

where (hot vs. cool season):

$Y_{i j k l}$............corrected value (dependent variable);

H...............mean value;

Season $_{i}$...hot $/$ cool season (hot season $=$ calving in Jun and July, $\mathrm{n}=105$; cool season = calving in September to May, $\mathrm{n}=105$ );

Year ........year of beginning service period $(1=1997-1998 \mathrm{n}=70 ; 2=1999-2001$ $\mathrm{n}=62 ; 3$ = above $2001 \mathrm{n}=78$ );

Milk $_{k}$........milk production in $1^{\text {st }}$ lactation ( 1 = to 5500 $\mathrm{n}=76 ; 2$ = 5501-7500 $\mathrm{n}=81 ; 3$ = above $7501 \mathrm{~kg} \mathrm{n}=53)$;

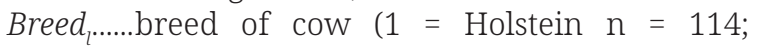
2 = Czech Fleckvieh $\mathrm{n}=96$ );

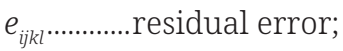

where (cool vs. cool season):

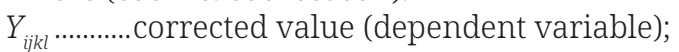

$\mu$................mean value;

Season $_{i} .$. COOL1/COOL2 season $($ COOL1 season = September to December $\mathrm{n}=58$; COOL2 season = January to May $n=58$ );

Year $_{j}$........year of beginning service period $(1=1997-1998 \mathrm{n}=23 ; 2=1999-2001$ $\mathrm{n}=37 ; 3$ = above $2001 \mathrm{n}=56$ );

Milk $_{k}$........milk production in $1^{\text {st }}$ lactation ( 1 = to 5500 $\mathrm{n}=32 ; 2=5501-7500 \mathrm{n}=55 ; 3$ = above 7501 kg $n=29)$;

Breed $_{l}$.......breed of cow $(1=$ Holstein $n=68 ; 2=$ Czech Fleckvieh $n=48$ );

$e_{i j k l}$............residual error.

Mean differences between estimated variables were tested at the $\mathrm{P}<0.05(+)$ level of significance.

The temperature difference between the two periods (hot vs. cool; COOL1 vs. COOL2) is shown in Tab. I. The table shows the temperature conditions 30 days after calving, which is the time of preparation of cows for the next pregnancy. The Temperature Humidity Index (THI), which includes the air temperature and relative humidity, was calculated according to the following equation:

Temperature-humidity index (THI) $=0.8 \times$ ambient temperature $+[(\%$ relative humidity $\div 100) \times$ $\times$ (ambient temperature-14.4)] + 46.4 (Buffington et al., 1981).

Maximum day temperature and day humidity were obtained from the Czech Hydro Meteorological Institute in Brno.

\section{RESULTS}

Tab. II presents basic statistical characteristics studied databases (hot vs. cool; COOL1 vs. COOL2) and difference between twins pairs (t-test dependent samples). Differences between twins in different temperature season (hot vs. cool) was 17.2 days (131.9 vs. 114.7 days), whereas differences between twins in temperature similar season (COOL1 vs. COOL2) was only 4.67 days (114.8 vs. 119.4 days). Differences between season (hot vs. cool) was significant.

I: Weather conditions 30 days after calving siblings pairs

\begin{tabular}{lccc}
\hline \multirow{2}{*}{ Month of calving } & \multirow{n}{*}{} & \multicolumn{2}{c}{ Weather conditions $30^{\text {th }}$ day after calving } \\
\cline { 3 - 4 } & & Mean of daily max.temparature; \pm SD $\left({ }^{\circ} \mathrm{C}\right)$ & Mean THI index; \pm SD \\
\hline HOT season & 105 & $24.9 ; 4.11$ & $75.9 ; 6.95$ \\
COOL season & 105 & $11.7 ; 8.24$ & $53.1 ; 14.17$ \\
\hline COOL1 season & 58 & $3.9 ; 6.5$ & $39.6 ; 10.98$ \\
COOL2 season & 58 & $11.6 ; 8.65$ & $53.2 ; 14.91$ \\
\hline
\end{tabular}

HOT season = calving in June and July

COOL season = calving from September to May

COOL1 season = calving from September to December

COOL2 season $=$ calving from January to May 
By comparing the influence of the hot and cool period (Tab. III, Fig. 2) on reproduction it was found that during the hot summer season the service period was significantly longer than during the cool months (difference +19.1 days). During the hot summer season the average service period was $133.8 \pm 6.27$ days, while in cold months it was only $114.7 \pm 6.15$ days. This difference is also evident from the graphic presentation (Fig. 2). The variability of these results was comparable in both cases. Comparison was also made between twins calved in September to December and between January to April (COOL1 vs. COOL2 season, Tab. IV). In this case the differences in length of service period between twins were lower and not statistically significant (difference of 5.8 days).

Another variable included in the study was milk production in the $1^{\text {st }}$ lactation. Although there were no significant differences between the studied milk production groups (to 5500; 5501-7500; above $7501 \mathrm{~kg}$ ), it was obvious that cows with higher milk production had a longer time to pregnancy (longer service period). In the database including comparison of twins in the hot and cool period of the year (Tab. III) the length of service period for animals with low production (up to $5500 \mathrm{~kg}$ ) was shorter $114.3 \pm 7.71$ days than in cows with milk production between $5501-7500 \mathrm{~kg}$ (SP = $126.4 \pm 6.98$ days) or in the case of high-yield cows over $7501 \mathrm{~kg}$ of milk (SP $=132.1 \pm 9.65$ days). A consistent tendency was found also for twins in a database contain only the cool season of the year (Tab. IV).

Apropos breed (Tab. III and Tab. IV) there was a general tendency for a slightly longer service period in Holstein cows compared to the Czech Fleckvieh breed. In the case of animals with service period during the cold months (COOL1 vs. COOL2 season), these differences were significant (Holstein 126.7; Czech Fleckvieh 106.3 days). The effect of year was not significant. However, it is important to focused this effect, because there were differences between the years in service period. It can be assumed, that for some years this effect can be significant.

Tab. V and Tab. VI consist statistical characteristics (F ratio; $\mathrm{P}$ values) for the length of the service period. In the database hot vs. cool seasons, the effect of „season“ was shown to be significant effect $(\mathrm{P}=0.0282)$.

\section{DISCUSSION}

The results showing the impact of the hot summer period on reproduction are in agreement with other authors. Specifically, Oseni et al. (2004) found that spring calving is associated with the longest service period (166 days), while in the fall and winter season it is shorter (130; 150 days). Ray et al. (1992) found a longer service period and inferior reproduction traits in the hot season of the year. The authors reported for spring, fall and summer length of service periods 103; 103 and 119 days and for calving interval 378; 382 and 396 days respectively.

This tendency of deterioration of reproduction traits has been presented by a number of authors also in gametogenesis and embryogenesis, which manifest in the subsequent results in the length of service period (Putney et al., 1988; Bezdíček et al., 2015; Bezdíček et al., 2016). Putney et al. (1988) found an effect of heat stress on the proportion of degenerated embryos. They confirmed in heat stressed heifers only $20.7 \%$ of transferable embryos compared to $51.5 \%$ in heifers in the thermoneutral temperature zone. Bezdíček et al. (2015) reported reduced results for embryo transfer in the hot season in Holstein cattle. In the summer months the average number of embryos was significantly lower (3.15 pcs.), than in the cold season of the year (5.95 pcs.). In the hot season was found also a lower proportion of transferable embryos ( 2.25 pcs.) than in the cold period (3.80 pcs.).

A number of authors have also confirmed a reduction in milk production in the summer season, presented in this paper too. These findings are reported, for example, by André et al. (2011), who found loss of milk production duration of the heat stress $31.4 \pm 12.2 \mathrm{~kg}$ of milk/cow per year. Bernabucci et al. (2002) reported that daily milk production and protein percentages was significantly lower in summer by $10 \%$ ev. 9.9\%, than in spring (concretely milk 26.7 vs. 29.5 l/day; protein 3.01 vs. $3.31 \%$ ). On the other hand, season did no affect somatic cell count. Reduction in milk production due to heat stress was reported by Bernabucci et al. (2014) and in a following study where they found lower values of milk components (fat, protein, total solids, and solids-not-fat) in the summer months, lowest values of casein fractions (with the exception of $\gamma$-CN) and poorer milk coagulation properties but greater content of IgG and serum albumin.

Heat stress in cattle has been demonstrated for both production and reproduction traits. This should be acknowledged and during the hot season to arrange for cooling of the animals. One option is the use of cattle showers. This was shown to be effective for example, by Legrand et al. (2011), although there was great individual variability among animals in its use. In the hot summer season, shade is also important to reduce the heat load (Schütz et al. 2011).

\section{CONCLUSION}

The results showed a significantly longer service period in the summer months (133.8 days) than in the cold months of the year (114.7 days) and thus the influence of heat stress on the reproduction of the cows. In the case of comparing twins with a service period in the cold months (cold vs. cold season), these differences were lower and not significant (113.6 vs. 119.4 days). 
This work was supported by the student project IGA_PrF_2019_024 of the Palacky University and by Institutional research plan MZe CR RO1218 (26.2.2018). We would like to thank the „Czech Hydrometeorological Institute“ in Brno for the weather data too.

II: Length of service period (in days) and differences between twin pairs (dependent samples)

\begin{tabular}{|c|c|c|c|c|}
\hline Season & Mean (days) & $\pm \mathrm{SD}$ & $\mathrm{N}$ & $\mathrm{p}$ \\
\hline HOT & $131.9^{\mathrm{a}}$ & 66.88 & 104 & \multirow{2}{*}{0.0491} \\
\hline COOL & $114.7^{\mathrm{a}}$ & 57.71 & 104 & \\
\hline COOL1 & 114.8 & 46.43 & 58 & \multirow{2}{*}{0.6158} \\
\hline COOL2 & 119.4 & 56.24 & 58 & \\
\hline
\end{tabular}

$\mathrm{P}<0.05$ (a)

HOT season = Calving in June and July

COOL season $=$ Calving from September to May

COOL1 season = Calving from September to Dezember

COOL2 season $=$ Calving from January to May

III: LSM (ANOVA test) of the length of the service period between full siblings calved in the hot and cool seasons

\begin{tabular}{lcccc}
\hline & & Average of Service period (LSM) & Service period Std.Err. & N \\
\hline \multirow{2}{*}{ Season of calving } & HOT season & $133.8^{\mathrm{a}}$ & 6.27 & 105 \\
& COOL season & $114.7^{\mathrm{a}}$ & 6.15 & 105 \\
\hline \multirow{3}{*}{ Milk production } & 1 (to 5500 kg) & 114.3 & 7.71 & 76 \\
& 2 (5501-7500) & 126.4 & 6.98 & 81 \\
\hline \multirow{2}{*}{ Breed } & 3 (above 7500 kg) & 132.1 & 9.65 & 53 \\
\hline \multirow{2}{*}{ Yech Fleckvieh } & Holstein & 122.1 & 6.86 & 96 \\
& 1 & 126.4 & 6.08 & 114 \\
\hline
\end{tabular}

$\mathrm{P}<0.05$ (a)

HOT season $=$ Calving in June and July

COOL season $=$ Calving from September to May

IV: LSM (ANOVA test) of the length of service period between full siblings in two cool seasons (September to December compared to January to April)

\begin{tabular}{|c|c|c|c|c|}
\hline & & Average of Service period (LSM) & Service period Std.Err. & $\mathrm{N}$ \\
\hline \multirow{2}{*}{ Season of calving } & COOL1 season & 113.6 & 7.30 & 58 \\
\hline & COOL2 season & 119.4 & 7.43 & 58 \\
\hline \multirow{3}{*}{ Milk production } & 1 (to $5500 \mathrm{~kg}$ ) & 111.3 & 9.37 & 32 \\
\hline & $2(5501-7500)$ & 117.7 & 7.40 & 55 \\
\hline & 3 (above $7500 \mathrm{~kg}$ ) & 120.6 & 12.09 & 29 \\
\hline \multirow{2}{*}{ Breed } & Czech Fleckvieh & $106.3^{\mathrm{a}}$ & 8.57 & 48 \\
\hline & Holstein & $126.7^{\mathrm{a}}$ & 6.69 & 68 \\
\hline \multirow{3}{*}{ Year } & 1 & 123.1 & 11.97 & 23 \\
\hline & 2 & 112.8 & 8.77 & 37 \\
\hline & 3 & 113.6 & 7.56 & 56 \\
\hline
\end{tabular}

$\mathrm{P}<0.05$ (a)

COOL1 season $=$ Calving from September to December

COOL2 season $=$ Calving from January to May 
$\mathrm{V}$ : The basic statistical characteristic of the investigated effects (ANOVA test) - length of the service period (hot vs. cool season)

\begin{tabular}{lccc}
\hline \multicolumn{1}{c}{ Effect } & & $\mathrm{F}$ & $\mathrm{p}$ \\
\hline Season & 1 & 4.8883 & 0.0282 \\
Milk Production & 2 & 1.0220 & 0.3617 \\
Year & 2 & 1.4857 & 0.2288 \\
Breed & 1 & 0.2115 & 0.6461 \\
\hline
\end{tabular}

$\mathrm{R}^{2}=0.0229$

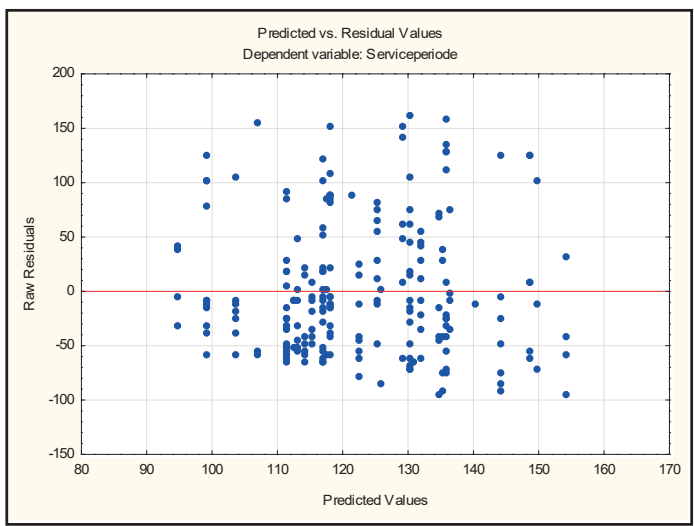

$1 \mathrm{a}$
VI: The basic statistical characteristic of the investigated effects (ANOVA test) - length of the service period (cool vs. cool season)

\begin{tabular}{lccc}
\hline \multicolumn{1}{c}{ Effect } & & $\mathrm{F}$ & $\mathrm{p}$ \\
\hline Season & 1 & 0.3654 & 0.5468 \\
Milk production & 2 & 0.1840 & 0.8322 \\
Year & 2 & 0.2804 & 0.7560 \\
Breed & 1 & 3.6504 & 0.0587 \\
\hline
\end{tabular}

$\mathrm{R}^{2}=0.0024$

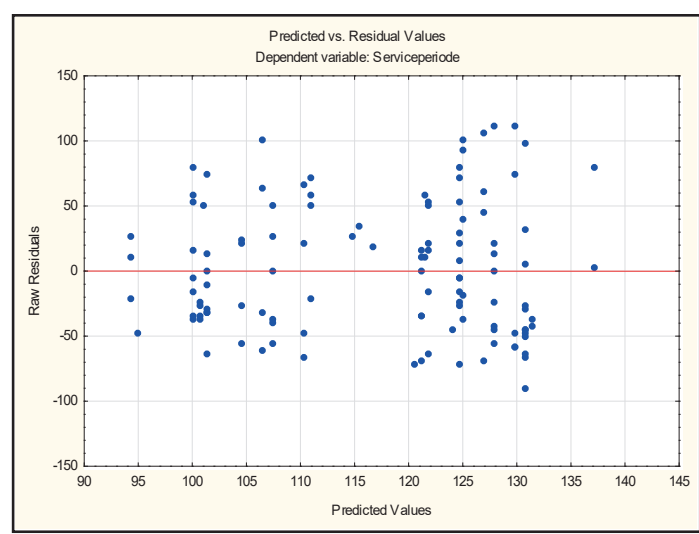

$1 \mathrm{~b}$

1: Graph of residuals of the full-siblings; service period in different seasons: (1a the hot vs. cool season, $1 b$ the COOL1 vs. COOL2 season)

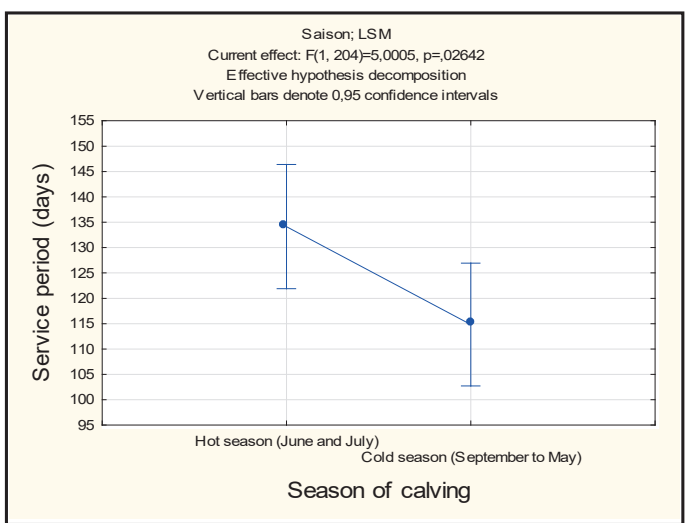

$2 \mathrm{a}$

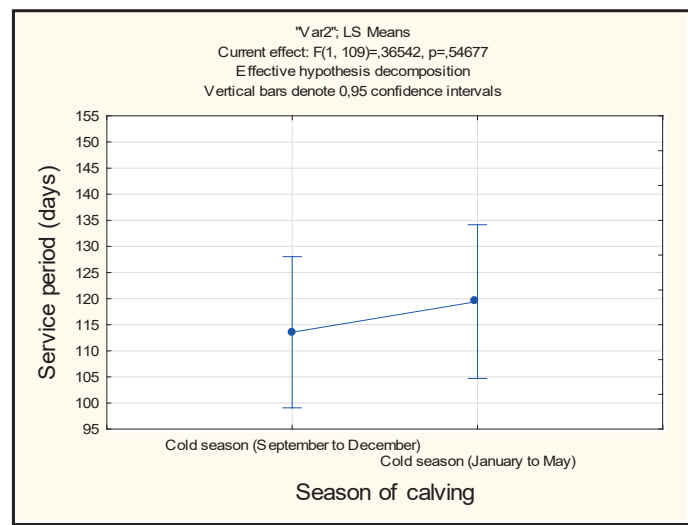

$2 \mathrm{~b}$

2: Graph of the length of the service period (LSM) of the full siblings in different seasons: (2a the hot vs. cool season, $2 b$ the COOL1 vs. COOL2 season)

\section{REFERENCES}

AL-KATANANI, Y. M., WEBB, D. W. and HANSEN, P. J. 1999. Factors affecting seasonal variation in 90-day nonreturn rate to first service in lactating Holstein cows in a hot climate. J. Dairy Sci., 82(12): 2611-2616.

AL-KATANANI, Y. M., PAULA-LOPES, F. F. and HANSEN, P. J. 2002. Effect of season and exposure.to heat stress on oocyte competence in Holstein cows. J. Dairy Sci., 85: 390-396.

ANDRÉ, G., ENGEL, B., BERENTSEN, P. B. M., VELLINGA, T. V. and OUDE LANSINK, A. G. J. M. 2011. Quantifying the effect of heat stress on daily milk yield and monitoring dynamic changes using an adaptive dynamic model. J. Dairy Sci., 94: 4502-4513.

BERNABUCCI, U., LACETERA, N., RONCHI, B. and NARDONE, A. 2002. Effects of the hot season on milk protein fractions in Holstein cows. Anim. Res., 51: 25-33. 
BERNABUCCI, U., BASIRICÒ, L., MORERA, P., DIPASQUALE, D., VITALI, A., PICCIOLI CAPPELLI, F. and CALAMARI, L. 2014. Effect of summer season on milk protein fractions in Holstein cows. J. Dairy Sci., 98: 1815-1827.

BEZDÍČEK, J., MAKAREVICH, A., STÁDNÍK, L., KUBOVIČOVÁ, E., LOUDA, F., HEGEDÜŠOVÁ, Z., HOLÁSEK, R., DUCHÁČEK, J. and STUPKA, R. 2015. Analysis of factors affecting the quantity and quality of embryo production in superovulated cows. Züchtungskunde, 87(4): 249-264.

BEZDÍČEK, J., MAKAREVIČ, A., OLEXIKOVA L., KUBOVIČOVÁ, E. and VRÁNOVÁ, Z. 2016. The influence of season on the ovarian activity and oocyte yield in cattle - in czech. Slovenskýveterinársky časopis, 41(3-4): 173-174.

COLLIER, R. J., COLLIER, J. L., RHOADS, R. P. and BAUMGARD, L. H. 2008. Genes involved in the bovine heat stress response. J. Dairy. Sci., 91: 445-454.

CHEBEL, R. C., SANTOS, J. E. P., REYNOLDS, J. P., CERRI, R. L. A., JUCHEM, S. O. and OVERTON, M. 2004. Factors affecting conception rate after artificial insemination and pregnancy loss in lactating dairy cows. Anim. Repr. Sci., 84: 239-255.

De RENSISI, F., MARCONI, P., CAPELLI, T., GATTI, F., FACCIOLONGO, F., FRANZINI, S. and SCARAMUZZI, R. J. 2002. Fertility in postpartum dairy cows in winter or summer following estrus synchronization and fixed time AI after the induction of an LH surge with GnRH or hCG. Theriogenology, 58(9): 1675-1687.

DIKMEN, S., ALAVA, E., PONTES, E., FEAR, J. M., DIKMEN, B. Y., OLSON, T. A. and HANSEN, P. J. 2008. Differences in thermoregulatory ability between slick-haired and wild-type lactating Holstein cows in response to acute heat stress. J. Dairy Sci., 91: 3395-3402.

FERREIRA, R. M., AYRES, H., CHIARATTI., M. R., FERRAZ, M. L., ARAUjO, A. B., RODRIGUES, C. A., WATANABE, Y. F., VIREQUE, A. A., JOAQUIM, J. C., SMITH, L. C., MEIRELLES, F. V. and BARUSELLI, P. S. 2011. The low fertility of repeat-breeder cows during summer heat stress is related to a low oocyte competence to develop into blastocysts. J. Dairy Sci., 94, 2383-2392.

HERNÁNDEZ-CERÓN, J., CHASE, JR. C. C. and HANSEN, P. J. 2004. Differences in heat tolerance between preimplantation embryos from Brahman, Romosinuano, and Angus Breeds. J. Dairy Sci., 87: 53-58.

LEGRAND, A., SCHÜTZ, K. E. and TUCKER, C. B. 2011. Using water to cool cattle: Behavioral and physiological changes associated with voluntary use of cow showers, J. Dairy Sci., 94: 3376-3386.

MATHEVON, M., BUHR, M. M. and DEKKERS, J. C. M. 1998. Enviromental, management, and genetic factors affecting semen production in Holstein bulls. J. Dairy Sci., 81(12): 3321-3330.

MORTON, J. M., TRANTER, W. P. MAYER, D. G. and JONSSON, N. N. 2007. Effects of environmental heat on conception rates in lactating dairy cows: critical periods of exposure. J. Dairy Sci., 90: 2271-2278.

NICHI, M., BOLS, P. E. J., ZUGE, R. M., BARNABE, V. H., GOOVAERST, I. G. F., BARNABE, R. C. and CORTADA, C. N. M. 2006. Seasonal variation in semen quality in Bos indicus and Bos taurus bulls raised under tropical conditions. Theriogenology, 66(4): 822-828.

OSENI, S., MISTZAL, I., TSURUTA, S. and REKAYA, R. 2004. Genetic components of days open under heat stress. J. Dairy Sci., 87: 3022-3028.

PAULA-LOPES, F. F., CHASE, JR. C. C., AL-KATANANI, Y. M., KRININGER III, C. E., RIVERA, R. M., TEKIN, S., et al. 2003. Genetic divergence in cellular resistance to heat shock in cattle: differences between breeds developed in temperate versus hot climates in responses of preimplantation embryos, reproductive tract tissues and lym-phocytes to increased culture temperatures. Reproduction, 125: 285-294.

PUTNEY, D. J., DROST, M. and THATCHER, W. W. 1988. Embryonic development in superovulated dairy cattle exposed to elevated ambient temperatures between Days 1 to 7 post insemination. Theriogenology, 34: 195-209.

RAVAGNOLO, O. and MISZTAL, I. 2002. Effect of heat stress on non return rate in Holsteins: Fixedmodel analyses. J. Dairy Sci., 85: 3101-3106.

RAY, D. E., JASSIM, A. H., ARMSTRONG, D. V., WIERSMA, F. and SCHUH, J. D. 1992. Influence of season and microclimate on fertility of dairy cows in a hot-arid environment. Int. J. Biometeorol., 36: 141145.

ROCHA, A., RANDEL, R. D., BROUSSARD, J. R., LIM, J. M., BLAIR, R. M., ROUSSEL, J. D., GODKE, R. A. and HANSEL, W. 1998. High environ-mental temperature and humidity decrease oocyte quality in Bos taurus but not in Bos indicus cows. Theriogenology, 49: 657-665.

RYAN, D. P., PRICHARD, J. F., KOPEL, E. and GODKE, R. A. 1993. Comparing early embryo mortality in dairy cows during hot and cool seasons of the year. Theriogenology, 39: 719-737.

SCHÜLLER, L. K., BURFEIND, O. and HEUWIESER, W. 2014. Impact of heat stress on conception rate of dairy cows in the moderate climate considering different temperature - humidity index thresholds, periods relative to breeding, and heat load indices. Theriogenology, 81: 1050-1057.

SCHÜTZ, K. E., ROGERS, A. R., COX, N. R., WEBSTER, J. R. and TUCKER, C. B. 2011. Dairy cattle prefer shade over sprinklers: Effects on behavior and physiology. J. Dairy Sci., 94: 273-283. 
